\title{
The CASE FOR A NeW COMPassionate Release Statutory Provision
}

\begin{abstract}
ADELINA IFTENE ${ }^{*}$
In the last decade there has been a steady growth in the number of federally incarcerated people aging in prisons. These individuals have a long list of medical needs while they present a low risk to communities. However, this category of people tends to spend more time in prison than their younger counterparts and face difficulties in being released. Using original empirical data, as well as the existing literature, I argue that a high number of these individuals need to be released through a compassionate release mechanism. This article has two purposes. One is to show that compassionate release does not really exist in Canada. Section 121 of the Corrections and Conditional Release Act - parole by exception - is the closest Canada has to release on humanitarian grounds, but it fails to fulfill this role. The second purpose is to argue that the lack of a functional compassionate release provision is unacceptable, particularly in the context of the increase among the prison population of medical conditions associated with aging. I maintain that a system which is not flexible enough to consider extreme post-incarceration circumstances of an offender, and does not allow for a modification of the place where individuals serve their sentence based on these circumstances, is disconnected from any medical, penological, humanitarian, or constitutional requirements. Finally, I provide a set of recommendations for the redrafting of section 121 .
\end{abstract}

\section{TABle OF Contents}

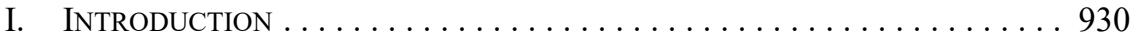

II. TYPES OF EARLY RELEASE $\ldots \ldots \ldots \ldots \ldots \ldots \ldots \ldots \ldots \ldots \ldots \ldots . \ldots . \ldots \ldots$

III. Application of Conditional Release and Compassionate Release . . . . . . . . . . . . . . . . . . . 933

A. Conditional Release as a Dying Breed ............ 933

B. Compassionate Release as an EXtinguished BREed ..... 936

IV. ARguments for a Compassionate Release Mechanism . . . . . . . 938

A. The High Needs — Low-Risk Argument . . . . . . . . . . . 939

B. The Double Standard Argument $\ldots \ldots \ldots \ldots \ldots \ldots \ldots . \ldots 942$

C. The Penological Argument . ................... 943

D. The Statutory and Constitutional ARguments . . . . . . . . 945

E. The Financial ARgument $\ldots \ldots \ldots \ldots \ldots \ldots \ldots$. . . . . . . . 947

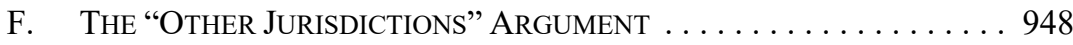

V. RECOMMENDATIONS FOR THE CREATION

OF A COMPASSIONATE RELEASE SYSTEM $\ldots \ldots \ldots \ldots \ldots \ldots \ldots \ldots 950$

A. A New Provision IN THE CCRA ................ 950

B. CRITERIA For Compassionate RELEASE $\ldots \ldots \ldots \ldots \ldots \ldots 950$

C. CSC'S CONCOMITANT OBLIGATION FOR POST-RELEASE SUPPORT . . . . . . . . . . . . . 951

D. Who Should Provide the Evidence of Disease? . . . . . . . . 951

PhD, SSHRC Postdoctoral Research Fellow, Osgoode Hall Law School, York University. The author is indebted to Allan Manson, Basil Alexander, and the anonymous reviewers for comments and suggestions on the earlier drafts of this article. The study on which this article is based was financed by the Social Science and Humanities Research Council through a Joseph-Armand Bombardier Award. The opinions expressed and the potential shortcomings belong entirely to the author. 


\section{E. Who Should File a Compassionate Release Request? . . . . . 951 \\ F. AdJudication of COMPASSIONATE RELEASE REQUESTS . . . . . . . 951

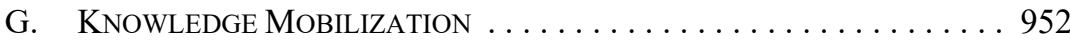

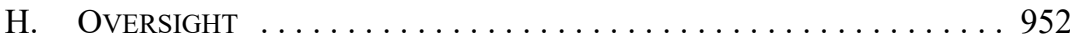

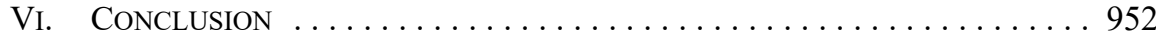

Don't you want to be alive before you die?

- Anthony Doerr ${ }^{1}$

\section{INTRODUCTION}

The Canadian federal parole system is regulated by the Corrections and Conditional Release $A c t^{2}$ and Regulations. ${ }^{3}$ This legislation provides for a number of types of early release options for incarcerated people, with the purpose of contributing "to the maintenance of a just, peaceful and safe society by means of decisions on the timing and conditions of release that will best facilitate the rehabilitation of offenders and their reintegration into the community as law-abiding citizens."4 The most common types of early release are the day parole and the full parole. Unfortunately, the parole system is flawed and lacks efficiency. The criteria for release are difficult to identify and the decisions are often unpredictable. Anthony Doob, Cheryl Webster, and Allan Manson showed that if the system would be abolished altogether, the federal prison population would increase only by 4.5 percent. $^{5}$

A type of compassionate release, "parole by exception," is included in the legislation among other types of parole. While section 121 of the CCRA established parole by exception for people suffering from serious health conditions, ${ }^{6}$ the way this section is framed, regulated, and applied shows that this provision has very little to do with compassion or release on humanitarian grounds. Nonetheless, an appropriate compassionate release provision is necessary in an era where the penitentiary population is aging rapidly, as this raises issues that have never faced our correctional system before. Twenty-five percent of the population is currently over 50 and it is believed that this number will continue to rise. ${ }^{7}$ Based on the results of a study I conducted with aging prisoners in Canadian penitentiaries, ${ }^{8}$ and similar studies conducted in foreign jurisdictions, ${ }^{9}$ it appears that prisons cannot properly

Anthony Doerr, All the Light We Cannot See (New York: Scribner, 2014) at 270.

SC 1992, c 20 [CCRA].

Corrections and Conditional Release Regulations, SOR/92-620 [CCRR].

CCRA, supra note 2, s 100.

Anthony N Doob, Cheryl Marie Webster \& Allan Manson, "Zombie Parole: The Withering of Conditional Release in Canada" (2014) 61:3 Crim LQ 301 at 315.

CCRA, supra note 2, s 121.

Correctional Investigator, Annual Report of the Office of the Correctional Investigator 2014-2015, by Howard Sapers (Ottawa: Correctional Investigator of Canada, 2015) at 2, online: $<$ www.oci-bec.gc.ca/ $\mathrm{cnt} / \mathrm{rpt} / \mathrm{pdf} /$ annrpt/annrpt20142015-eng.pdf $>$.

$8 \quad$ Adelina Diana Iftene, Older Federal Inmates: Needs, Institutional Treatment, and Legal Implications, (PhD Thesis, Queen's University Faculty of Law, 2015) [unpublished] [Iftene, Older Inmates]; Adelina Iftene, "Unlocking the Doors to Canadian Older Inmate Mental Health Data: Rates and Potential Legal Responses" (2016) 47 Intl J L \& Psychiatry 36 [Iftene, "Mental Health"]; Adelina Iftene, "The Pains of Incarceration: Aging, Rights, and Policy in Federal Penitentiaries" (2017) 59:1 Can J Corr 63.

$9 \quad$ See e.g. Ronald H Aday, Aging Prisoners: Crisis in American Corrections (Westport: Praeger, 2003); Melvin Delgado \& Denise Humm-Delgado, Health and Health Care in the Nation's Prisons: Issues, Challenges, and Policies (Lanham: Rowman \& Littlefield, 2009); Stephan Arndt, Carolyn L Turvey \& Michael Flaum, "Older Offenders, Substance Abuse, and Treatment" (2002) 10:6 American J Geriatric 
meet the enhanced needs of seniors. From medical care to infrastructure, programs, and conditions for parole, the system is designed for young, healthy people who will live to be released.

Even if the current conditional release system was systematically reformed, it is unlikely that it would be able to single-handedly respond to the needs of the aging population. Parole is not a termination of the sentence. Rather, it means moving the setting where the sentence is being served from prison to community, to enable low-risk individuals to reintegrate and to continue their rehabilitation process. Thus, rehabilitation and reintegration are key. With better criteria for evaluating risk and rehabilitation potential, more people would be released before they would need compassionate release. Sometimes, however, people get sick, even terminally ill, before they have a chance to prove, even by the most reasonable and wellapplied criteria, that they are rehabilitated. Moreover, as they get sicker, the risk they present decreases, but so does their potential to reintegrate as productive citizens. Continued incarceration in such circumstances is, however, ill-advised for a variety of reasons. Nonetheless, the grounds for moving the sentence to the community would not be based on rehabilitation and reintegration, but rather on humanitarian reasons.

The argument for a different compassionate release system will be built as follows: First, I will describe the general parole system and its flaws. Second, I will argue that the current parole by exception is not an efficient compassionate release provision, and that even if the parole system were improved, it could not replace compassionate release. Third, I will bring six arguments why a proper and distinct compassionate release mechanism is needed in the Canadian criminal justice system. Fourth, shaped as recommendations, I will depict the steps needed to create a real compassionate release mechanism.

\section{TYPES OF EARLY RELEASE}

In Canada, all prisoners are eligible to apply for release before their sentences expire. Early release, or conditional release, is regulated at the federal level by the $C C R A^{10}$ and the $C C R R,{ }^{11}$ which prescribe both the criteria and the process for the different forms of release.

Criminological studies have shown that early release is successful in "ensuring the longterm protection of the public."12 Early release allows individuals to be part of the community and to begin building a life on the outside, while remaining under supervision for the balance of their sentence. Thus, at the heart of the provisions regulating this type of release are two key concepts: reintegrating individuals and reducing the risk to community. These concepts are present in the mission statement of the Parole Board of Canada (PBC), ${ }^{13}$ the

Psychiatry 733; Patricia L Colsher et al, "Health Status of Older Male Prisoners: A Comprehensive Survey" (1992) 82:6 American J Public Health 881; Jason S Ornduff, "Releasing the Elderly Inmate: A Solution to Prison Overcrowding” (1996) 4:1 Elder LJ 173.

Supra note 2.

Supra note 3.

Doob, Webster \& Manson, supra note 5 at 304.

Parole Board of Canada, "The Parole Board of Canada's Vision and Mission," online: $<\mathrm{https}: / / \mathrm{www}$. canada.ca/en/parole-board/corporate/the-parole-board-of-canada-s-vision-and-mission $>$ [PBC, "Mission Statement"]. 
administrative body charged by the CCRA with hearing parole requests and making early release decisions. ${ }^{14}$

The CCRA provides a number of early release types. The first form is day parole, where an individual is released into the community for limited periods of time before being fully released. The eligibility criteria with regard to the time served for each type of offender are regulated in section $119 .{ }^{15}$

The second type of early release is known as full parole. Full parole allows for the release of incarcerated offenders before they reach the completion of their sentence. Except when she committed an offence that triggers a life sentence, a prisoner is generally eligible to be released after she served one third of the sentence. ${ }^{16}$ An individual serving life as a maximum sentence is eligible to apply for early release after seven years. ${ }^{17}$ The Criminal Code provides different criteria for those sentenced for murder. People imprisoned for first degree murder are eligible to apply for parole after 25 years served, while second degree murder carries a period of parole ineligibly between 10 and 25 years. ${ }^{18}$ In addition to these limits, the Criminal Code permits the judge to increase the parole ineligibility period to a half of the sentence or to ten years, whichever comes first. ${ }^{19}$ The Protecting Canadians by Ending Sentence Discounts for Multiple Murders Act ${ }^{20}$ now allows for people convicted of multiple murders to be sentenced to life with parole ineligibility of considerably more than 25 years. Since introduced, people have been given parole ineligibility periods of up to 75 years. ${ }^{21}$ This is arguably akin to a life sentence without possibility of parole.

Individuals who, for various reasons, do not get paroled, have the semi-automatic right to be released on the day when they have served two thirds of their sentence. This is called statutory release. Those individuals subject to it, similarly to those paroled, will serve the rest of their sentence in the community, under supervision. ${ }^{22}$ Statutory release is automatic in that no application is required, but the $\mathrm{PBC}$ may deny it at the recommendation of the Correctional Service of Canada (CSC), and continue to detain an individual convicted of certain offences deemed particularly high risk. ${ }^{23}$ If that is the case, the individual will serve the whole sentence in prison. ${ }^{24}$ In any case, the sentence is deemed completed only when the warrant expires. ${ }^{25}$

CCRA, supra note 2, ss 103-11.

Ibid, s 119.

Ibid, s 120(1).

Ibid, s 120(2).

Criminal Code, RSC 1985, c C-46, s 745.

Ibid, s 743.6.

SC 2011, c 5 .

See e.g. $R$ v Baumgartner, 2013 ABQB 761, 578 AR 87; $R$ v Bourque, 2014 NBQB 237, 427 NBR (2d)

259; $R$ v Ostamas, 2016 MBQB 136, 329 Man R (2d) 203.

CCRA, supra note 2, s 127.

Correctional Service of Canada, "Detention," Commissioner's Directive No 712-2 (Ottawa: CSC, 23 April 2015), online: <www.csc-scc.gc.ca/acts-and-regulations/712-2-cd-eng.shtml> [CD 712-2]; CCRA, ibid, s 129.

24 For the release procedure upon warrant expiry see Correctional Service of Canada, "Release Process," Commissioner's Directive No 712-4 (Ottawa: CSC, 1 April 2014) at paras 31-39, online: <www.cscscc.gc.ca/acts-and-regulations/712-4-cd-eng.shtml>.

CCRA, supra note $2, \mathrm{~s} 128(3)$. 
Two special cases of early release are the royal prerogative of mercy and parole by exception. The royal prerogative is not granted by the PBC but rather it is an executive attribute exercised by the Governor General of Canada in the name of the Her Majesty the Queen. It is not governed by the CCRA. ${ }^{26}$ While the royal prerogative is largely discretionary, and technically anybody is eligible to apply, parole by exception is regulated by section 121 of the CCRA. By all accounts, this would appear to be Canada's version of compassionate release. ${ }^{27}$ The provision states that parole may be granted at any time to an offender if he is terminally ill, if his mental or physical health is likely to suffer damage if incarceration will continue, if continued incarceration for that person would constitute excessive hardship not reasonably foreseen at the time of sentencing, or if he is subject to an order of surrender under the Extradition Act. ${ }^{28}$ However, individuals sentenced to life in prison or to an indeterminate sentence ${ }^{29}$ are not eligible to apply for this type of parole..$^{30}$ This means that those serving the longest sentences are outside its reach.

\section{Application of Conditional Release AND COMPASSIONATE RELEASE}

\section{A. Conditional Release as a Dying Breed}

In their seminal study, Doob, Webster, and Manson analyzed the use of conditional release in the federal and provincial systems. They concluded that it is in fact so little used that, if it were altogether abolished, it would make almost no numeric difference. Based on the current number of people on parole versus those incarcerated in the federal system, the authors found that if full parole were abolished, the federal incarcerated population would raise by only 4.5 percent. ${ }^{31}$ Overall, Canada's incarceration rate per 100,000 people is currently 113.1. If conditional release would be abolished, the rate would increase to 116.1 or it would be 2.7 percent higher. ${ }^{32}$ Its use appears to be unnecessarily low because the rate of reoffending for people on parole is very low..$^{33}$ In the words of Doob, Webster, and Manson: "[I]f the purpose of parole is to facilitate the safe and peaceful reintegration of prisoners into society, it is failing." 34

It is, however, mentioned in the CCRA, ibid, s 110 .

Correctional Investigator, Annual Report of the Office of the Correctional Investigator 2012-2013, by Howard Sapers (Ottawa: Correctional Investigator of Canada, 2013) at 20-21, online: <www.ocibec.gc.ca/cnt/rpt/pdf/annrpt/annrpt20122013-eng.pdf > [Annual Report 2012-2013].

SC 1999, c 18.

In Canada, an offender may be incarcerated for an indeterminate period of time if he is labelled a "dangerous offender" or "DO." This label can be applied by a judge, upon sentencing, to an individual found guilty of three or more violent offences in his lifetime. Dangerous offenders are generally treated as "lifers" (those sentenced to life in prison). Under the current regime, unlike "lifers," DOs are eligible for parole after serving 7 years, after which they are entitled to a parole hearing every second year. However, most of them spend extended periods of time in prison and, even when released, like lifers, they are kept under lifetime supervision. Essentially, their warrant never expires and neither category is entitled to statutory release. See Criminal Code, supra note 18, ss 753, 761(1) CCRA, supra note 2, s 121(2).

Doob, Webster \& Manson, supra note 5 at 315.

Ibid at 316.

See ibid at 322 (in the fiscal year of 2012/13, only three people on parole for violent offences had their parole revoked, compared to 1,190 who successfully completed their full parole). See also Ivan Zinger, "Conditional Release and Human Rights in Canada: A Commentary" (2012) 54:1 Can J Corr 117 at 119-20.

Supra note 5 at 317. 
A low rate of use is not the only problem presented by conditional release. The parole process is poorly regulated, and thus, decisions are quite unpredictable. Aside from the eligibility dates for different types of sentences, the CCRA and CCRR do not provide other operational criteria that should be considered by PBC members in their conditional release decision-making. It is, however, clear that such criteria need to be centred on risk and on helping the individual reintegrate into the community. ${ }^{35}$ More criteria are provided by the PBC's Decision-Making Policy Manual for Board Members. ${ }^{36}$ This manual elaborates on the main factors which include criminal history, family relationships, employment, substance abuse, the gravity of current offences, breaches of previous conditional releases, history of reoffending, history of violent behaviour, attempts to escape, recommendations of the sentencing judge, and victim impact statements. Other factors include the offender's involvement in the correctional programs, diagnosis of a mental disorder, behaviour during incarceration, and the existence of a release plan. Signs of change in behaviour, as revealed by the manner in which the prisoner completed his correctional plan and by professional report assessments ${ }^{37}$ (such as a psychological report), are also important. ${ }^{38}$ One commissioner's directive - a policy document that sets a standard for all federal institutions - mentions institutional behaviour and completion of correctional plans (as well as attitude during completion) as information to be collected and presented to the $\mathrm{PBC}$, in each case, by the parole officer. ${ }^{39}$ Consideration of these factors is explained through the objective of avoiding an undue risk to society. ${ }^{40}$ However, factors like health status, disability, the physical capacity of committing crime, and age, are not listed at all, even though they may have at least as much influence on the very capacity of an individual to reoffend. More bluntly, it would appear that the PBC is required to consider whether a convicted person has received and responded appropriately to correctional programs, but is not encouraged to consider whether he is totally paralyzed.

Studies conducted in Canada point out a serious problem with parole decisions: they rely on sometimes subjective and unpredictable criteria, as well as on factors at least partially outside the prisoner's control (such as completion of correctional programs or having a release plan). Renée Gobeil and Ralph Serin argued that the only factors that appear to consistently influence parole decisions are gender (women are released more often), type of crime (sex offenders are released more often, while those charged with domestic violence less often), ethnicity (Aboriginal status negatively impacts release decisions), and risk assessment reports. ${ }^{41}$ Other demographic factors, the victim impact statement, or mental health issues, appear to be completely irrelevant to such decisions. More recently, Kelly

PBC, Manual, supra note 36, s 4.3(12).

CCRA, supra note 2, s 100 . pdf $>$ [PBC, Manual]. PBC, Manual, supra note 36, ss 2.1(8)-(13). eng.shtml $>$ [CD 712-1].

Parole Board of Canada, Decision-Making Policy Manual for Board Members, 2nd ed (Ottawa: PBC, 2017), online: $<$ https://www.canada.ca/content/dam/canada/parole-board/migration/008/093/dpm-mpd.

For the content of the case managers' report see Correctional Service of Canada, "Progress Against the Correctional Plan," Commissioner's Directive No 710-1 (Ottawa: CSC, 23 July 2015), online: $<$ www.csc-scc.gc.ca/acts-and-regulations/710-1-cd-eng.shtml $>$ [CD 710-1]. This stipulates that the report will document the institutional adjustment and attitude of the prisoner, the programs he participated in, his institutional employment history, as well as the professional counselling he received.

Correctional Service of Canada, "Pre-Release Decision-Making," Commissioners Directive No 712-1 (Ottawa: CSC, 23 January 2015), Annex E, online: <www.csc-scc.gc.ca/acts-and-regulations/712-1-cd-

Renée Gobeil \& Ralph C Serin, "Preliminary Evidence of Adaptive Decision Making Techniques Used by Parole Board Members” (2009) 8:2 Intl J Forensic Mental Health 97 at 100-102. 
Hannah-Moffat and Carolyn Yule conducted a similar study with a focus on female offenders. ${ }^{42}$ They revealed that the main factors considered were length of the total sentence (the shorter the sentence, the likelier the release), lack of psychological assessments, evidence of change mainly through program participation, and attitude during incarceration. Other personal characteristics, including the type of offence, demographic factors, mental illness, or substance abuse did not play into the decision-making. ${ }^{43}$ In 2009 , Michael Jackson and Graham Stewart published a report on the state of correctional affairs. ${ }^{44}$ They were critical about the fact that most criteria for release are geared towards rewarding "good behaviour" (which is not a stated purpose of early release) and are often out of the prisoner's control; they cited such factors as "motivation," fulfillment of correctional plan, attitude and statements made by the offender, early engagement in the parole process, and securing employment upon release. ${ }^{45}$

In 2015, I concluded a research project regarding the quality of life and the challenges faced by older prisoners incarcerated in federal institutions. ${ }^{46}$ During the data collection, I visited seven institutions with varying levels of security, and spoke to 197 imprisoned men over the age of $50 .{ }^{47}$ Everyone over 50 who volunteered was interviewed. About 33 percent of participants were sentenced to life in prison, about 12 percent had an indeterminate sentence, and the rest were serving determinate sentences. ${ }^{48}$ The difficulties raised by the parole process were mentioned by numerous participants to the study, regardless of whether they were serving a determinate or indeterminate sentence. ${ }^{49}$ Prisoners felt they were not granted parole because they did not have a release plan or post-release support, and because they were not able to complete the correctional plan required for parole. ${ }^{50}$ More than half of the people serving life (who were about one third of the sample) mentioned that they had not completed their correctional plan by their first parole eligibility date, generally because there were no spots available in the program. ${ }^{51}$ On the other hand, almost 45 percent of the sample was over $60 .^{52}$ Some of these mentioned already being retired when they entered prisons. Others just grew old in prison. While most of them were working in prison (about 80 percent), they mentioned that at their age and level of disability, finding work on the outside was highly problematic. ${ }^{53}$ This negatively impacted their reports: they were not seen as good candidates for parole because they were old, unemployable, and difficult to house. However, such matters point to institutional shortcomings: the availability of release plans (which support individuals in finding housing and employment in the community) and other programs are the responsibility of the CSC. These matters do not reflect the individual's risk or rehabilitation potential, only the failures of the system.

42

Kelly Hannah-Moffat \& Carolyn Yule, "Gaining Insight, Changing Attitudes and Managing 'Risk': Parole Release Decisions for Women Convicted of Violent Crimes” (2011) 13:2 Punishment \& Society 149.

Ibid at $157-59$

$44 \quad$ Michael Jackson \& Graham Stewart, “A Flawed Compass: A Human Rights Analysis of the Roadmap to Strengthening Public Safety" (2009), online: <www.justicebehindthewalls.net/resources/news/ flawed Compass.pdf $>$.

Ibid at $\overline{109-15 .}$

Iftene, Older Inmates, supra note 8.

Ibid at 137 .

Ibid at 142 .

Ibid at 167, 183, 187, 190-91.

Ibid at 188-89.

Ibid at 167-69, 190-91.

Ibid at 141.

Ibid at 196-97. 


\section{B. Compassionate Release AS AN EXTINGUISHED BREED}

The purpose of parole by exception under the CCRA is to ensure that people (a) who are terminally ill, (b) whose health is incompatible with incarceration, (c) whose health is threatened by continued incarceration, or (d) are under an extradition order are released. ${ }^{54}$ Despite the increasing number of old and sick prisoners, this section has barely been used and, as already pointed out, is not available for at least 40 percent of the sample (those serving life or indeterminate sentences). ${ }^{55}$

In my study, approximately 70 percent of the participants had no disciplinary record since turning $50,{ }^{56}$ about 12 percent were 70 years old and over, ${ }^{57}$ and many suffered from diseases which included final stage cancer, advanced multiple sclerosis, dementia, serious heart conditions, incontinence, epilepsy, diabetes, and severe physical disabilities. ${ }^{58}$ However, none of the participants were ever encouraged to apply for parole by exception by their case managers and other counsellors, or had ever even heard of it. ${ }^{59}$

For the minority of elderly prisoners who could theoretically apply for parole by exception, it appears that section 121 is extremely difficult to access. In his 2010-2011 Annual Report, the Correctional Investigator addressed the issue of compassionate release in a chapter related to death and dying in prison. ${ }^{60}$ He noted that between 2005 and 2010 there were 22 requests for parole under section 121 and that 12 were granted. In addition, there were 21 applications for release by royal prerogative and none were granted. ${ }^{61}$ In his 2012-2013 report, the Correctional Investigator reiterated the issue of compassionate release, and criticized the fact that "[f]ew ... inmates [are allowed] to die with some semblance of dignity in the community." ${ }^{62}$ Additional testimony to the scarcity of parole by exception is the fact that the Federal Court has only heard two judicial reviews of negative PBC decisions. Neither were based on a request for release due to medical issues, but were rather grounded in section 121(d): release while awaiting deportation. ${ }^{63}$

There are a number of problems with the current provision, which render it of such little use. First, the provision is poorly regulated, it does not provide for a coherent and expeditious process, and it is unduly restrictive. Section 121 is regulated by Commissioner's Directive 712-1 "Pre-Release Decision-Making." "64 Unfortunately, the directive does not bring more clarity, but only reiterates the text of section 121 and states that the $\mathrm{PBC}$ will

CCRA, supra note 2, s 121(1).

Ibid, s 121(2); Iftene, Older Inmates, supra note 8 at 142.

Iftene, Older Inmates, ibid at 174.

Ibid at 141 .

Ibid at 145,159 .

Ibid at 282 .

Correctional Investigator, Annual Report of the Office of the Correctional Investigator 2010-2011, by Howard Sapers (Ottawa: Correctional Investigator of Canada, 2011) at 34-35, online: <www.ocibec.gc.ca/cnt/rpt/pdf/annrpt/annrpt20102011-eng.pdf> [Annual Report 2010-2011].

Ibid at 34 .

Annual Report 2012-2013, supra note 27 at 20.

Hutchins v Canada (National Parole Board), [1993] 3 FCR 505; Daoud v Canada (Attorney General) (1997), 133 FTR 266. The issue was also mentioned prior to the CCRA in $R v$ McDonald (1981), 56 CCC (2d) 1 (Ont H Ct J).

64 Supra note 39 at paras 51-60. 
determine if the section's criteria are met. ${ }^{65}$ There is no direction on how such a determination will be made. The main shortcoming of section 121 is reinforced by the directive. Those sentenced to life in prison are ineligible to apply, "unless they are terminally ill." ${ }^{\prime 66}$ Thus, the offence committed — perhaps decades earlier — determines eligibility, not health or low-risk status. The directive does mention that people in this group can apply for a royal prerogative of mercy. ${ }^{67}$ But as shown above, such release has not been granted to anyone in over 10 years. $^{68}$

Second, the conditions stated in the provision are extremely difficult to meet because of the procedure for such applications. An application for parole by exception requires "substantial evidence" given by a prison doctor that the prisoner is suffering from a disease incompatible with incarceration. ${ }^{69}$ Rarely do prison health professionals seem willing to give such evidence in writing. ${ }^{70}$ By making such a judgment, the health professional could be seen as raising a liability issue, which is unlikely to be a good professional move. In contrast, refusing to grant "substantial evidence," even where the individual is severely ill, carries no risk to the health practitioner.

Third, despite the humanitarian grounds enumerated for compassionate release in section 121 , the criteria taken into account are disconnected from these grounds, partly because parole by exception is seen and treated as if it were incorporated in the general parole system. The legislation governing parole by exception is situated under the general parole heading, both in the legislation and in policy documents. This suggests that compassionate release is seen as serving the same purpose as the other early release provisions (safe reintegration and rehabilitation), as opposed to a humanitarian purpose. CD 712-1 states that the information to be forwarded to the Board by parole officers are the same as for regular parole, with emphasis on the offender's completion of his correctional plan, his criminal history, and his institutional behaviour. ${ }^{71}$ By overlapping the information required for a section 121-based decision with that which is needed for general parole, CD 712-1 abolishes any hope that section 121 is grounded in humanitarian purposes. As noted above, older people have difficulty fulfilling the regular parole criteria, and such criteria are not always relevant for proving rehabilitation and risk. For compassionate release, where only health and risk status should matter, not only is the relevance of such factors even more questionable, but the chances of very sick individuals meeting these factors is less likely. Understandably, completing correctional plans and working to build a release plan might not be a dying person's priority.

In Canada, compassionate release is essentially an extinguished subgroup of a dying breed. The failures of the general parole system are likely partially to blame for the failure of compassionate release. Improving the parole system should include consolidating the role

Ibid at para 55

Ibid at para 56.

Ibid.

Annual Report 2010-2011, supra note 60 at 34.

Ibid at 35 .

Correctional Investigator, Annual Report of the Office of the Correctional Investigator 2009-2010, by Howard Sapers (Ottawa: Correctional Investigator of Canada, 2010) at 28-29, online: <www.oci-bec.gc. ca/cnt/rpt/pdf/annrpt/annrpt20092010-eng.pdf>.

Supra note 39, Annex E. 
that the CSC has in helping individuals to fulfill their correctional plans, providing them with post-release support, as well as creating more predictable release criteria that account for age and illness. Such changes will allow for old, low-risk individuals with rehabilitative potential (provided age-appropriate support is given) to serve the remainder of their sentence in the community. Rehabilitation, however, means more than being low-risk, hence these concepts are treated as separate conditions in the legislation. Being rehabilitated does imply being low-risk: the offender has learned from his mistakes and is committed to reintegrate into society and be a productive citizen (by going to work or school, staying away from the wrong crowd, and so forth). However, a terminally ill individual — or one suffering from a permanent disability - may not be able to be rehabilitated. He may have had a very bad behavioural history in prison up to the moment he got ill. He may not care about the consequences of what he has done. He may not care about his outside family, or have any concept of remorse. Yet, he is still low-risk because he is physically incapacitated. In discussing those near death, Jalila Jefferson-Bullock, an American scholar, sugested that

[i]n such situations, the granting of compassionate release relies on a determination that impending death extinguishes any threat that an otherwise dangerous offender might levy upon release, and on a basic, fundamental belief that, due to the inmate's altered circumstances, humanity and decency demand early release. $^{72}$

In addition, if this individual was serving life, even with great rehabilitation potential he would not be considered for parole for up to 25 years (and in special circumstances up to 75). It is for this small — but growing — group of individuals in exceptional life circumstances that a good compassionate release system is needed.

We turn now to six arguments supporting the conclusion that, in special circumstances, the option to release people without concern for the time they served or their rehabilitation potential is needed in our criminal justice system.

\title{
IV. Arguments For A Compassionate Release Mechanism
}

\begin{abstract}
Compassionate release is justified by two philosophies: one legal and one medical. The legal justification is that impeding death has cancelled a terminally ill prisoner's debt to society, thereby re-harmonizing the scales of justice so that release, prior to the completion of the prisoner's sentence, is warranted. The medical virtue of compassionate release is grounded in basic humanity, and commands that we treat dying prisoners as people, worthy of a dignified death. ${ }^{73}$
\end{abstract}

There is something to be said about the morality of keeping someone in prison because they do not meet parole eligibility criteria, despite the fact that they are close to death or deteriorating due to their imprisonment. However, a moral debate is not the purpose of this article. I will, instead, focus on some pragmatic reasons why there is a need for a working compassionate release provision. First, I will explain that older prisoners have very high 
needs and present a very low risk. Their needs are not properly addressed in prison, partly because of imperfections in the system and partly because penitentiary security is not compatible with nursing home-type care. Second, I will show that sentencing judges have been concerned with issues pertaining to the health of accuseds when making their decisions. Therefore, it appears that if an accused is sick at the time of sentencing, he has a better chance of receiving a compassionate sentence than of receiving compassion if his circumstances change the day after sentencing. This double standard is unjustified. Third, the penological purposes of incarceration need to be reflected in parole decisions. Penological goals do not call for compassionate release. However, it can be argued that impending death annuls the penological interests of society to have the individual incarcerated. Hence, while penological goals need to be met when making a conditional release decision, they do not deny the possibility of creating a compassionate release system for circumstances so extreme that the very rationale of imprisonment is displaced. Fourth, continuing to incarcerate very sick individuals in an environment that cannot provide them with appropriate medical care might raise serious legal challenges. It is possible that some types of necessary medical care cannot be provided even after prison medical care reform. Fifth, it is very expensive to keep and provide for sick people in prison. From a cost-benefit point of view, it is illogical to keep low-risk individuals in prison, on taxpayers' money, when they could be cared for on the outside at a lower public cost. Decarceration would also help solve some of the overcrowding issues which are currently raising financial, safety, and health concerns in correctional institutions. Sixth, other jurisdictions have superior compassionate release systems which seem to be working better than what Canada currently has. Therefore, arguments that the same cannot be done here need to be questioned.

Considered separately, each of the above arguments might not be sufficient for claiming a compassionate parole procedure. Taken together, however, they paint a pragmatic picture of a better functioning and more humane system.

\section{A. The High NeEdS - Low-Risk ARgument}

The aforementioned study that I conducted identified a series of issues that rendered older prisoners highly susceptible to chronic illnesses, disability, victimization, and isolation, even while having very short records of disciplinary problems. ${ }^{74}$ Medical care appeared inadequate and this increased the challenges these individuals faced. Some of the problems noted in the study were:

- 99 percent of the individuals suffered from at least one chronic condition.

- Conditions ranged from arthritis and cancer to multiple sclerosis, dementia, Lou Gehrig's disease, and post-stroke effects.

- 54 percent of the participants reported a continuing or permanent physical disability. 
- Over 80 percent of the disabled individuals reported being in chronic pain, significantly more than those not reporting a disability.

- Some institutions did not have appropriate infrastructure (such as elevators, handrails, disability friendly washrooms or showers) to accommodate those with physical challenges.

- While 50 percent of those reporting chronic pain mentioned taking prescribed medication for it, only 20 percent said it was effective.

- The only medication available for all types of pain was Tylenol $3 .^{75}$

- $\quad$ Prescribed medication needed to be picked up daily, in person, from the infirmary. In three institutions the line formed outside, year-round, and the older prisoners were often the last to pick it up because younger offenders would regularly cut in line.

- Four institutions did not have a nurse on site at all times.

- $\quad$ Only 27 percent of the participants mentioned receiving the medical items they needed (such as an extra pillow for back pain, orthopedic shoes, canes or walkers), while only 6 percent had a peer caregiver assigned.

- There was a statistically relevant connection between disability and both peer abuse (such as threats, stigma, and physical abuse) and staff abuse. The latter was manifested mostly as name calling or pranks (such as officers hiding inmates' wheelchairs or canes).

- $\quad$ Five percent were terminally ill.

- There were no palliative care units.

- $\quad$ Palliative care was discretionary, depending on the institution, and hence was not automatically available. Individuals requiring this care were generally given morphine and were excused from some prison activities (such as work or walking to the canteen). However, there was no palliative care team available, and family visits were as restricted as they were for the general population.

- Terminally ill prisoners were housed in the same units as everybody else.

- Regardless of how sick they were, all prisoners had to undergo the same system to see a doctor. They had to put in a request to see the nurse. They would be called a few days later and sometimes sent to the doctor. After the general physician had 
seen them, they were sometimes placed on a list to see a specialist. The wait time to see a specialist could be as long as two years.

On the other hand, participants reported low rates of disciplinary incidents:

- Twenty-three percent reported spending time in segregation after turning 50, only 20 percent of which was for violent behaviour.

- Most of those reporting spending time in segregation also reported being diagnosed with a mental illness.

- Thirty-one percent reported they had been charged with a disciplinary offence, of which only 6.5 percent reported for a violent offence. Similarly, most of those reporting being charged also reported a mental illness. ${ }^{76}$

The study does not provide information about reoffending — in part, of course, because these prisoners are unlikely to be released. The only relevant fact is that none of the individuals who had earlier been paroled were returned to prison with a new charge. Rather, they had their parole revoked because of breaches of administrative conditions. ${ }^{77}$ American scholars have also noted the inverse relationship between age and crime, and called the process "aging out" of crime. ${ }^{78}$ Similarly, it was noted that reoffending has not been associated with compassionate release in states that apply it regularly. ${ }^{79}$

To conclude, many elderly individuals appear to be sick and low-risk. Completion of correctional programs, employment opportunities, attitude behind bars, manifestation of remorse - factors typically seen as related to diminution of risk — are clearly not, for this group, as relevant as physical incapacitation of the individual by age or health. The CSC is struggling to provide for their enhanced needs. A better parole system would do so.

However, 30 percent of the individuals interviewed had not reached their first parole eligibility date. Some of them were already very sick, with one being terminally ill and two suffering from stage 1 dementia. Others had been in prison for as long as 45 years and presented very little society reintegration potential. Nonetheless, they were very ill, inappropriately treated in prison, and arguably, physically incapable of committing any crime. A better parole procedure would still exclude these individuals. The only possibility of ever releasing them would be through a compassionate release system that explicitly takes into account their actual circumstances and operates independently of normal parole eligibility dates.

For a complete account of the findings itemized above and discussion surrounding those findings, see Iftene, Older Inmates, supra note 8 at 142-94.

CCRA, supra note 2, ss 135-135.1; Correctional Service of Canada, "Post-Release Decision Process," Commissioner's Directive No 715-2 (Ottawa: CSC, 1 June 2016) at para 16, online: <www.cscscc.gc.ca/acts-and-regulations/715-2-cd-eng.shtml $>$ (the suspension of release will occur for any breach of conditions).

78 Kathleen Auerhahn, "Sentencing Policy and the Shaping of Prison Demographics" in John J Kerbs \& Jennifer M Jolley, eds, Senior Citizens Behind Bars: Challenges for the Criminal Justice System (Boulder: Lynne Rienner, 2014) 21 at 38.

79 Gregory J O'Meara, “Compassion and the Public Interest: Wisconsin's New Compassionate Release Legislation" (2010) 23:1 Federal Sentencing Reporter 33 at 35. 


\section{B. The Double Standard Argument}

Compassion for the accused's circumstances and section 121 have been discussed in a number of sentencing decisions. ${ }^{80}$ In Coulson, Judge Allen said it would be unfair not to consider the precarious state of the defendant's health for sentencing purposes, considering that in prison, the offender can apply for compassionate release on this basis. Hence, he mitigated the sentence so it was not unduly harsh. The defendant received 2 years to be served in the community instead of 4 years in prison. ${ }^{81}$ In reaching his decision, Judge Allen mentioned a wide array of similar cases where extenuating conditions were considered and mitigated sentences were granted. Such conditions included post-stroke recovery, ${ }^{82}$ muscular dystrophy in a 71 year old defendant,${ }^{83}$ depression, ${ }^{84}$ eye surgery, ${ }^{85}$ colon cancer, ${ }^{86}$ mental illness, ${ }^{87}$ physical disability, and drug addiction. ${ }^{88}$ Other similar cases were cited in Coulson. ${ }^{89}$

Some judges have shown an acute awareness of the fact that compassionate release is, in reality, not readily available. In $R$. $v$. Ruez, Judge Langdon mentioned that the unfortunate fact that parole by exception would most likely not be granted to the defendant because of the PBC's stance on narcotics importers. ${ }^{90}$ In R. v. DeWael, Judge Clements recommended that the CSC release the defendant immediately after sentencing based on parole by exception on medical grounds. ${ }^{91}$ In R. v. Morrissey, Justice Fuerst drastically reduced the time for parole eligibility in a murder case because he acknowledged the fact that for a person sentenced to life, parole by exception was not available. ${ }^{92}$ Justice Fuerst recommended that the medical condition of the inmate be of primary consideration on his first parole date. ${ }^{93}$

Under these circumstances, it appears that there are two separate standards: one for people who are already sick at the time of sentencing, and another for those who become sick during incarceration or as they grow old in prison. While judges tend to use their discretion to minimize the harshness of the punishment depending on individual's health, the PBC does not, even though it has the legal tools to do so. These cases also illustrate the tension between the need to impose a legally prescribed sentence or parole eligibility date, and judges' awareness that the accused's health will not be compatible with incarceration for that long. Said differently, judges realize that those suffering poor health at the time of sentencing will suffer more each day that they are incarcerated and, therefore, try to take that into account. These tensions show, on one hand, the need for a separate release system that accounts for actual circumstances of the prisoner, and on the other, the current lack of judicial and

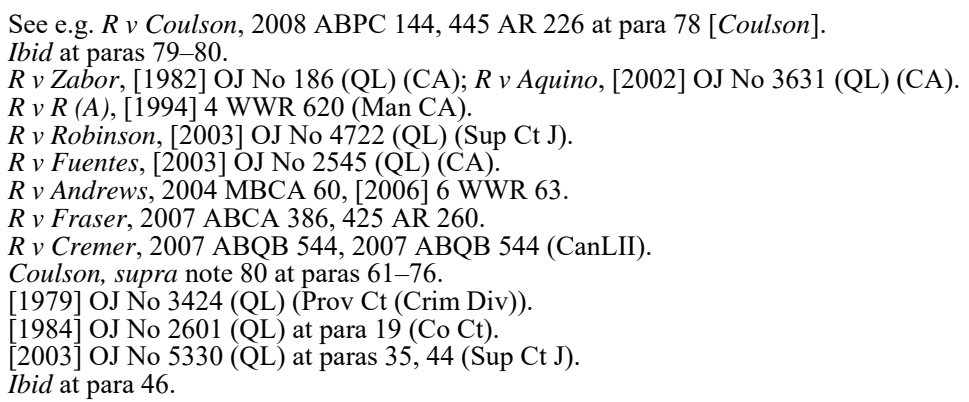


administrative cooperation needed to ensure the coherence of the process, the humanity of sentences, and the safety of the communities. As I will suggest later in this article, because of the very peculiar factors considered for compassionate release, it would be better if compassionate release responsibilities were taken away from parole boards and given to sentencing judges. This would allow for consistency of treatment in a system that the judiciary appears to understand better than administrative boards.

\section{The Penological Argument}

Modern penal philosophy and the Criminal Code offer a range of explanations for incarcerating people. These vary from general and individual deterrence to denunciation and incapacitation. In general, all of these explanations can be grouped in two categories: retributive (desert) and utilitarian (protect society from crime and criminals). ${ }^{94}$ Though often using the same language, the goals of sentencing and those of imprisonment are different. The Criminal Code provides purpose and principles of sentencing, ${ }^{95}$ but for those sent to prison, it allows the prison authorities and the parole board to determine exactly how they serve the sentence. The CCRA allows the changes in a prisoner to determine where a sentenced individual spends his time. Those who are seen as having changed their character, and are consequently seen as good candidates for rehabilitation, are supposed to serve their sentence in the community. Those who remain high risk, or become an even higher risk than when they started their sentences, are supposed to serve most (or sometimes even all) their sentence is prison. In Canada, the stated purpose of the correctional system relies heavily on utilitarian factors, chiefly the protection of society and rehabilitation of offenders. ${ }^{96}$

In considering arguments for releasing an incarcerated individual, it is important to reflect on the justification for placing him or her in prison in the first place. Through the regular parole system, release is seen as part of the correctional program. It is envisioned as a means of helping with one's rehabilitation and community reintegration. Compassionate release, however, is not part of the correctional process. Would correctional goals be frustrated when releasing someone on humanitarian grounds? As I argue below, I believe that while the penological goals of incarceration do not necessarily demand for the creation of a compassionate release mechanism, they are not infringed in the cases where such a mechanism is used. More precisely, in many cases where incarcerated individuals find themselves in extenuating life circumstances, the goals of incarceration can no longer be met, hence their release does not frustrate any penological principles.

Jefferson-Bullock recently argued that the penological goals of incarceration do not operate effectively if the circumstances of the offender change radically. ${ }^{97}$ This argument is pertinent when discussing those incarceration goals that are offender-related - generally those in the utilitarian category - as opposed to offence-related. Because the offender's circumstances refer to aspects other than guilt, the reasons for rejecting the need to meet these penological goals in cases of compassionate release are often not culpability based. 
These penological goals include incapacitation, rehabilitation, and deterrence. JeffersonBullock argues that: "Theories of punishment do not justify sustained incarceration for prisoners who are 'too ill or cognitively impaired to be aware of punishment, too sick to participate in rehabilitation, or too functionally compromised to pose a risk to public safety." $" 98$

The circumstances of many of the participants in my study have changed radically since sentencing. Most of them, as the data show, were no longer a danger to society. Thus, the goal of incapacitation had already been met due to natural aging: correctional intervention was no longer needed. On the other hand, as important a goal as it is, rehabilitation cannot be achieved unless there is an active engagement on the part of the prisoners. Many of the participants to my study had been active in their youth, completed programs, and attempted to apply for parole. But once disability and illnesses struck, their main focus was survival. The rehabilitative mechanism used in correctional models and designed for able-bodied individuals cannot possibly have the same impact on this category of prisoners. Nor is rehabilitation, any more, an appropriate correctional goal: there is no need to rehabilitate someone who cannot offend, and the need to be socially rehabilitated is trumped by the need to be taken care of if very sick. It is also doubtful that there is any need for individual deterrence in the case of some seriously ill individuals, such as people reaching different stages of dementia or suffering from severe memory loss. Their condition both incapacitates and deters them from committing any more crimes.

However, supporters of offence-related (retributive) incarceration goals might argue that society has an interest in punishing individuals regardless of their capacity to reoffend or to perceive the incarceration as a direct effect of their actions. Retribution is seen as necessary in order to rebalance the societal order that has been disturbed by the offender. ${ }^{99}$ Nonetheless, von Hirsch and Ashworth, leading penology scholars, have argued that in order for the retributive or just desert purposes to be reached, the punishment needs to be proportionate to the offence. ${ }^{100}$ If proportionality is not respected, punishment becomes arbitrary and the societal balance tilts in the opposite direction. In the case of old and sick offenders, whom the correctional systems cannot humanely manage, the sentence becomes unduly harsh because of the change in their life circumstances. The punishment is harsher than what the judge likely intended at sentencing and what similarly situated younger offenders are experiencing. Thus, the continued incarceration of such individuals does not meet even the retributive goals of incarceration.

Moreover, even if one could argue that retributive goals are always met, the state has other interests, ${ }^{101}$ such as financial and moral interests. William Berry, an American scholar, has argued that in the case of the old and the sick, these other state interests outweigh the penological purposes. ${ }^{102}$ This argument is harder to make when attempting to release individuals through regular parole. Parole is part of the correctional rehabilitation process.

Von Hirsch \& Ashworth, supra note 94 at 13.

Ibid at 101-102; see also William W Berry III, "Extraordinary and Compelling: A Re-Examination of the Justifications for Compassionate Release" (2009) 68:4 Md L Rev 850 at 874.

101 Berry, ibid at 882.

102 Ibid at 853-75. 
Thus, the same rationales that govern incarceration should apply to conditional release. The individual has served enough time to fulfill the retributive goals of incarceration and has reached a point where its utilitarian purposes can be better met in the community. This may not be, and should not have to be, the case for very sick individuals. In such cases, the penologically governed incarceration and release systems should give way to a distinct, humanitarian-based release process.

\section{The Statutory AND Constitutional Arguments}

The treatment of sick seniors engages statutory and constitutional rights. According to section 86 of the CCRA, the CSC is under the obligation to provide every inmate with "essential health care," and "reasonable access to non-essential ... health care." 103 As well, the provision of health care must conform to professionally accepted standards. While there are serious deficits in caring for seniors in Canada, certain services are generally available for everyone on the outside, such as pain management, proper dental care, preventive medical care, cancer screening, and so on. ${ }^{104}$ Similarly, some initiatives that exist in the community, such as program integration, home support, treatment options, discussions about advanced directives, self-care information sessions and brochures, palliative care options, diet programs, mental health services, and environment adjustments, ${ }^{105}$ are nowhere to be found in prison. However, failure to provide the same level of care available in the community is a breach of legal obligations. This could give rise to an action based in negligence or to a remedy of mandamus. ${ }^{106}$

In addition, compliance with Charter rights is mandatory when devising any form of state policy. The data collected in my study suggest that there may be some issues regarding compliance of prison policies and practices with the human rights framework. Three Charter sections come specifically to mind in this context. First, section 12 guarantees everyone's right to be free from cruel and unusual treatment and punishment. ${ }^{107}$ This section has been interpreted to apply to conditions of confinement. ${ }^{108}$ Thus, if certain conditions are so grossly disproportionate as to outrage the standard of decency, they may be found unconstitutional. For example, requiring someone in chronic pain to stand outdoors for one hour a day to pick up pain medication might constitute cruel and unusual treatment. If efficient treatment or

Supra note 2 , s 86 .

See e.g. Canadian Institute for Health Information, Health Care Use at the End of Life in Atlantic Canada(Ottawa: CIHI, 2011), online: $<\mathrm{https}$ ://secure.cihi.ca/free products/end_of_life_2011_en.pdf $>$; Canadian Institute for Health Information, Exploring the 70/30 Split: How Cañada's Health Care System is Financed (Ottawa: CIHI, 2005), online: <https://secure.cihi.ca/free_products/FundRep_ EN.pdf>.

See e.g. Organisation for Economic Co-operation and Development, Long-Term Care for Older People (Paris: OECD Publishing, 2005), online: $<$ www.oecd-ilibrary.org/social-issues-migration-health/longterm-care-for-older-people 9789264015852-en>; Mental Health Commission of Canada, Guidelines for Comprehensive Mental Health Services for Older Adults in Canada (Calgary: MHCC, 2011), online: $<$ www.mentalhealthcommission.ca/sites/default/files/mhcc seniors guidelines_1.pdf $>$; Government of Canada: Action for Seniors (Ottawa: Government of Canada, 2014), online: $<$ www.publications.gc.ca/ collections/collection_2014/rhdcc-hrsdc/HS64-25-2013-eng.pdf>.

For a review of tort based litigation in the prison context, see Adelina Iftene, Lynne Hanson \& Allan Manson, "Tort Claims and Canadian Prisoners" (2014) 39:2 Queen's LJ 655.

Canadian Charter of Rights and Freedoms, s 12, Part I of the Constitution Act, 1982, being Schedule $\mathrm{B}$ to the Canada Act 1982 (UK), 1982, c 11 [Charter].

$R v$ Smith, [1987] 1 SCR 1045; Trang v Alberta (Edmonton Remand Centre), 2010 ABQB 6, 475 AR $1 ; R v$ Munoz, 2006 ABQB 901, 411 AR 257. 
medical supplies that would ease the pain associated with old age diseases are not generally available, and if the environment or infrastructure of institutions adds disproportionately to the challenges elderly prisoners face, it may be that such treatment grossly exceeds the punishment these people have been sentenced to. ${ }^{109}$

Second, section 7 states that "[e]veryone has the right to life, liberty and security of the person and the right not to be deprived thereof except in accordance with the principles of fundamental justice." ${ }^{\prime 10}$ Section 7 has been interpreted to protect physical liberty, freedom from exposure to health risks, control over one's body, and psychological integrity. ${ }^{111}$ In the past, it was found that legislation indirectly limiting access to medical care, ${ }^{112}$ and ministerial decisions that restrict access to health care, ${ }^{113}$ endanger life and security of the person in a manner incompatible with the fundamental principles of justice. It is possible that some policies related to pain management (such as the prohibition of a wide variety of painkillers, assistive devices, and cell-to-cell distribution of medication), for prisoners who essentially lack any control over their medical treatment, may do the same. ${ }^{114}$

Section 15 of the Charter states that "[e]very individual is equal before and under the law and has the right to the equal protection and equal benefit of the law without discrimination and, in particular, without discrimination based on race, national or ethnic origin, colour, religion, sex, age or mental or physical disability." "115 Section 15 has been interpreted to apply to both direct and indirect discrimination. ${ }^{116}$ As such, treating everybody the same does not ensure that section 15 is respected. When the same treatment has disproportionate effects on a certain category of people based on their race, nationality, religion, sex, age, or mental or physical disability, the state may take affirmative action for the benefit of the disadvantaged group, especially since section 15(2) insulates affirmative action programs from section 15 challenges. ${ }^{117}$ When the same correctional policies and practices (such as distribution of medication, availability of supplies, types of discipline, and so forth) are applied on a onesize-fits-all basis, even though this may impose considerable hardship on aging people, concerns regarding indirect age-based discrimination emerge. ${ }^{118}$

Over two decades ago, Justice Arbour wrote in her report on the events at the Kingston Prison for Women that a sentence reduction should be granted in cases of gross mismanagement and illegalities in prisons, "such as to reflect the fact that the punishment

For an extended analysis of a section 12 challenge arising from elderly prisoner treatment, see Iftene, "Mental Health," supra note 8.

Charter, supra note $107, \mathrm{~s} 7$.

Peter W Hogg, Constitutional Law of Canada, 5th ed (Toronto: Carswell, 2007) at 47-5 to 47-15.

Chaoulli v Quebec (Attorney General), 2005 SCC 35, [2005] 1 SCR 791.

Canada (Attorney General) v PHS Community Services Society, 2011 SCC 44, [2011] 3 SCR 134.

See Iftene, Older Inmates, supra note 8 at 188-90.

Charter, supra note 107, s 15.

Law $v$ Canada (Minister of Employment and Immigration), [1999] 1 SCR 497.

Eldridge v British Columbia (Attorney General), [1997] 3 SCR 624; R v Kapp, 2008 SCC 41, [2008] 2 SCR 483.

118 See e.g. Correctional Service of Canada, "Food Services," Commissioner's Directive No 880 (Ottawa: CSC, 21 February 2000), online: <www.csc-scc.gc.ca/acts-and-regulations/880-cd-eng.shtml>; Correctional Service of Canada, National Essential Health Services Framework, obtained in April 2016 through an Access to Information Act request (Ottawa: CSC, 2015); Correctional Services of Canada, "Medication Distribution and Administration," obtained May 2016 through an Access to Information Act request (Ottawa: CSC, 10 July 2014). 
administered was more punitive than the one intended." 119 Compassionate release is not a remedy, but Justice Arbour's justification for sentence reduction can also serve as a justification for release on humanitarian grounds. For the old, the sick, those suffering from dementia, and those on their dying bed, their sentence has become much harsher than the judge anticipated because their life circumstances have changed radically. Some of the potential legal problems presented above could be rectified by making institutions more senior-friendly: improving infrastructure, diets, programming, the availability of painkillers, medical care, and so on. However, for prisoners with serious chronic or terminal illnesses, institutions cannot be improved enough. Indeed, prisons are not hospitals or nursing homes, nor should they be. There will always be security concerns, and these will always trump most other considerations. While there is no right to compassionate release per se, both prevention and redress for the infringement of prisoners' rights may lie within the framework for compassionate release.

\section{E. The Financial Argument}

Older prisoners are among the lowest risk individuals, but place the highest costs on prisons. Their decarceration would often make for a safe and financially sound decision. American data suggest that the yearly cost of incarcerating a geriatric individual is more than double the cost of imprisoning a younger person. ${ }^{120}$ Similar comparative data are not available in Canada, but a 2013 report indicates that it costs on average $\$ 114,289$ per year per male prisoner and $\$ 211,618$ per year per female prisoner. In comparison, the supervision of an offender in the community under the most costly form of early release (day parole) reaches $\$ 35,101 .{ }^{121}$ The costs are likely less for other forms of supervised release. Concerns regarding the costs of incarcerating sick individuals rise with the increase in the numbers of older prisoners. Although federal imprisonment rates have been fairly stable for more than 50 years, ${ }^{122}$ the proportion of older people admitted to federal penitentiaries in Canada has increased dramatically. In 1993-94, 12.2 percent of those admitted to federal facilities were 45 years of age or older. Twenty years later, in 2013-14, 24.1 percent of those admitted to federal custody were 45 years of age or older. Indeed, in 1993-94 there were 96 people of age 60 or older admitted to federal penitentiaries (2.1 percent of those admitted). By 2013-14 this had increased to 250 people of age 60 or older ( 4.9 percent of those admitted). ${ }^{123}$

In addition to saving money on medical care, a compassionate release program would help solve some problems associated with overcrowding. Overcrowding has been a consistent problem in the last few decades. In its 2009-10 report, the Office of the Correctional Investigator stated that overcrowding had increased by 50 percent in the previous few years, resulting in many prisoners sleeping in bunk beds or on the floor. The Correctional

Commission of Inquiry into Certain Events at the Prison for Women in Kingston (Ottawa: Public Works and Government Services Canada, 1996) at 101.

Jefferson-Bullock, supra note 72 at 555.

Doob, Webster \& Manson, supra note 5 at 324.

Cheryl Marie Webster \& Anthony N Doob, "Penal Reform 'Canadian Style': Fiscal Responsibility and Decarceration in Alberta, Canada" (2014) 16:1 Punishment \& Society 3, Figure I.

Public Safety Canada, "Corrections and Conditional Release Statistical Overview" (Ottawa: Public Safety Canada, 1998), online: <https://www.publicsafety.gc.ca/lbrr/archives/hv\%207415\%20s65\%2019 98-eng.pdf>; Public Safety Canada, "Corrections and Conditional Release Statistical Overview," (Ottawa: Public Safety Canada, 2014) online: $<$ https://www.publicsafety. gc.ca/cnt/rsrcs/pblctns/ccrso2014/2014-ccrs-eng.pdf>. 
Investigator suggested that double-bunking, whether for the short or long term, is never a solution. ${ }^{124}$ In his 2010-2011 report, the Correctional Investigator reported that about 13 percent of the population was double-bunked; he expected this would increase to 30 percent in the next three years. ${ }^{125}$ Overcrowding has dramatic consequences. In addition to increasing the costs on correctional services and taxpayers, the availability of medical services is reduced, the rates of infection increase, programs are limited, and inmate violence is increased. ${ }^{126}$ Some might argue that the money saved would be insignificant if the average cost of incarceration is compared to the cost brought by the needs of one more prisoner. However, if compassionate release could be used in the case of even a few hundred individuals - and based on the data available on older prisoners, there are many potential eligible candidates — the cost recovery could be accomplished by delaying a new building construction or closing an institution.

\section{F. The “Other Jurisdictions” Argument}

In 1994, two states - California and New Jersey — had compassionate release authorized by a court instead of a parole board. ${ }^{127}$ In California, the director of corrections made recommendations to the court, while in New Jersey, the inmate applied for it himself. In a survey regarding compassionate release in all states, it was deemed that these two jurisdictions were the most efficient in releasing people on compassionate grounds. The procedure was similar to sentencing, where the judge looked at all factors, with emphasis on new circumstances that arose. In most cases, the judge would either release the individual with or without supervision, or reduce the sentence. In all cases of terminal illness, judges ordered release without supervision. The author of the survey found that judges were comfortable with analyzing all the factors that would go into a release decision and tended to be more compassionate than parole boards. ${ }^{128}$

At the time of the survey, 18 states used parole as a mechanism for people needing compassionate release. In all 18 , the main criterion was that the prisoner was so ill that he did not present a threat to society. Proof of illness was needed. The degree and type of proof varied from state to state. A number of factors were taken into account, including the type of crime committed. Some states required that the prisoner be given between three and six months left to live in order to be eligible. Finally, all states required that the prisoner "have "someplace to go." "129 Some required placement in a medical institution. In some states the prisoner could apply directly, in others he had to be recommended to the parole board by the Director of Corrections. This type of parole was permanent, but supervision was required in most states, and revocation of parole was possible in cases of criminal activity or violation of conditions. This type of parole was regarded as "expeditious" and in most states the whole

Correctional Investigator, Annual Report of the Office of the Correctional Investigator 2009-2010, by Howard Sapers (Ottawa: Correctional Investigator of Canada, 2010) at 34-36, online: <www.oci-bec.gc. $\mathrm{ca} / \mathrm{cnt} / \mathrm{rpt} / \mathrm{pdf} /$ annrpt/annrpt20092010-eng.pdf>.

Supra note 60 at 38 .

See Adelina Iftene \& Allan Manson, "Recent Crime Legislation and the Challenge for Prison Health Care" (2013) 185:10 CMAJ 886.

Marjorie P Russell, “Too Little, Too Late, Too Slow: Compassionate Release of Terminally Ill Prisoners — Is the Cure Worse than the Disease?" (1994) 3 Widener J Pub L 799.

Ibid at $820-21$.

Ibid at 830 . 
process took no more than 30 days. ${ }^{130}$ Twenty years after the compassionate release survey was completed, states have improved their procedures, recognizing the limitations of the parole system in responding to the needs of the very ill. An innovative and efficient American program that brings together correctional institutions and law schools is POPS (Project for Older Prisoners). Run by a law professor at George Washington University, POPS is focused on helping non-violent older offenders who have served a substantial part of their sentence to obtain early release. ${ }^{131}$ By 2013, the program helped release over 500 prisoners with a very low rate of recidivism. ${ }^{132}$ The program is active in five states. The assessment to determine who is a good candidate is based on interviews with the offender, correctional staff, and the victims, and on a risk assessment. Once assessed as a good candidate, the law school students develop a release strategy for the offender (including residence, employment and finance plans) and present it to the parole board. ${ }^{133}$

Though less focused, there are other programs that help seniors who have obtained parole by offering post-release support. Geriatric and medical release programs are reasonably common (present in Alabama, Colorado, Connecticut, District of Columbia, Louisiana, Maryland, Missouri, North Carolina, New Mexico, Oklahoma, Oregon, Texas, Virginia, Washington, Wisconsin, and Wyoming), with the Senior Ex-Offender Program (SEOP) in San Francisco being particularly successful. ${ }^{134}$ An alternative to this is medical release, known as Chapter 405, in place in California. People who are unable to permanently perform activities of daily living will be released. Acknowledging that many prisoners will not be able to afford health care, the federal and state government share the cost for their care on the outside. Chapter 405 resulted from a cost-benefit analysis showing that this is much cheaper than paying for sick, low-risk inmates inside the prison. In 2010, California faced a \$20 billion dollar budget deficit. Apparently, the program allowed them to save a considerable amount — about $\$ 200$ million per year — by releasing incapacitated individuals while still continuing to supervise and support them. ${ }^{135}$

A European example of dealing with severely ill prisoners comes from France. As a result of a number of cases at the European Court of Human Rights holding that incarceration of very sick people amounts to a violation of article 3 of the European Convention for Human Rights, ${ }^{136}$ the right to be free from torture and cruel and unusual treatment or punishment, France added some modifications to its Code of Criminal Procedure. ${ }^{137}$ According to the new provision, a prison sentence may be suspended for prisoners whose life expectancy is threatened or whose health is incompatible with detention (with the exception of inmates held in special psychiatric units). The seriousness of the offence, the length of sentence, and

Ibid at $826-32$

RV Rikard \& Ed Rosenberg, "Aging Inmates: A Convergence of Trends in the American Criminal Justice System" (2007) 13:3 J Correctional Health Care 150 at 153-54.

Martha H Hurley, Aging in Prison: The Integration of Research and Practice, (Durham: Carolina Academic Press, 2014) at 157.

Kristie R Blevins \& Anita N Blowers, "Community Reentry and Aging Inmates" in John J Kerbs \& Jennifer M Jolley, eds, Senior Citizens Behind Bars: Challenges for the Criminal Justice System (Boulder: Lynne Rienner, 2014) 201 at 217-18; Aday, supra note 9 at 213-14. Blevins \& Blowers, ibid at 218.

Kendra Bertschy, "Chapter 405: The Time No Longer Needs to Fit the Crime for Dying Inmates" (2011) 42:3 McGeorge L Rev 641 at 645-76.

Convention for the Protection of Human Rights and Fundamental Freedoms, 4 November 1950, 213 UNTS 221 (entered into force 3 September 1953).

See art 720-1-1 C proc pén. 
the threat to society are irrelevant for the sentence suspension. The terminal state of an individual and incompatibility with detention are assessed by two independent physicians while the final decision rests with a judge. The release is subject to revocation if the individual's health improves. ${ }^{138}$

Creating a workable compassionate release system is difficult, and it must be the product of the particular legal and social context in which it is applied. However, it is worth noting that many foreign jurisdictions have improved their compassionate release systems over the last two decades and found it to be an important addition to their parole systems. Also, as argued above, no negative consequences (including risk to society) has ever been associated with compassionate release, while its utility in managing prison costs and contributing towards a more humane system has been noted. ${ }^{139}$

\section{RECOMMENDATIONS FOR THE CREATION OF A COMPASSIONATE RELEASE SYSTEM}

At the moment, section 121 of the CCRA is a useless provision. It adds nothing to the parole system and does not create true compassionate release opportunities. Section 121 needs to be repealed, with a humanitarian-based provision added in its place. The compassionate release provision must be regulated by the CCRR and commissioner's directives, separately from other forms of parole. Below, are some guidelines as to how this could be achieved.

\section{A. A New Provision in the CCRA}

A new provision will need to be separated from the general parole provisions, in order to illustrate the different rationale for its use. The humanitarian rationale needs to be clearly stated in the provision to prevent any future misinterpretations.

\section{B. CRITERIA FOR COMPASSIONATE RELEASE}

Health status (terminal illness and health incompatible with incarceration) should be the only criteria used for compassionate release. In order to reflect its humanitarian grounds, compassionate release will need to be available to all prisoners, regardless of length or type of sentence, or of duration of time already served. Other factors may collaterally be considered to prove diminished risk: psychological assessments, disciplinary record, report of the parole officer, and so forth. These factors, however, should not be determinative where medical evidence can establish that the prisoner is so sick that he could not reasonably be believed to pose a risk. 


\section{CSC'S CONCOMitant Obligation FOR POST-RELEASE SUPPORT}

Post-release plans and support should never be factors for release. That is not to say they should not exist, or that the prisoner could be released without ensuring that he has some place to go. However, this should be CSC's obligation, and should never be used as an argument against a prisoner's release. There are a variety of avenues through which such obligations could be met, some of them being illustrated by the American experience. For example, internal case-management that would help prisoners find nursing or retirement homes should be available. As well, cost sharing between CSC and the province would offer the support needed on the outside and increase the chances of inmates finding appropriate medical facilities that can take them in. As already mentioned with respect to the cost issue, it is implausible that providing decent living quarters outside of a prison could rival the cost of imprisonment in a secure facility.

\section{Who Should Provide the EVIDENCE OF DISEASE?}

A list of diseases and symptoms incompatible with incarceration should be put together by a committee of experts appointed by the government. This committee should include different types of physicians, including prison doctors. The list should not be exhaustive. The evidence of disease should be provided, and recommendations should be made, by a physician. However, to the extent that few prison physicians are willing to sign off that the prisoner's health is incompatible with incarceration, the link between the condition and the capacity of the individual to endanger society should be established by an independent physician. This should ensure objectivity in the process.

\section{E. Who SHOUld File A Compassionate Release ReQuest}

Currently, only prisoners and their parole officers can apply. Some prisoners are in a health condition that does not allow them to forward such an application, while some parole officers are not willing or do not have the expertise to recognize the need for making such recommendations. The family of the prisoner, as well as the prison doctor, must be allowed to forward requests for compassionate release when prisoners are incapable of doing so.

\section{F. AdJudication OF Compassionate Release ReQuests}

There needs to be a specialized body to adjudicate compassionate release requests. The number of old, sick people will increase and, if properly regulated, so will the number of compassionate release requests. As illustrated by the California, New Jersey and France experiences, a court seems to be the best functioning mechanism for granting release. In Canada, there are numerous sentencing cases in which judges took into account the health status of the accused in order to minimize the sentence. It would make sense to allow them to release the individual upon a radical change of circumstances, as well as to decide if and when continuing supervision upon release is needed. Judges are also highly familiar with 
balancing different factors and are not directly involved in the correctional process, which offers them enhanced objectivity. Other scholars have also agreed that placing the duty of hearing such requests upon a judge would best ensure fairness and competency. ${ }^{140}$ The judge assigned for such cases could be either a judge specializing in the particular matter, or someone who deals with sentencing on a regular basis. For judges deciding such cases, specialized training on matters related to the conditions of compassionate release (such as medical issues) should be expected.

If, for any reason, judges are not given such responsibilities, at the very least a special panel within the PBC should be created to hear compassionate release requests. This would allow for the appropriate training of the panel on medical issues likely to arise in such cases. Also, through experience, a special panel would be able to quickly and fairly assess all of the relevant factors. Compassionate release cases are time sensitive. As the correctional investigator has mentioned, ${ }^{141}$ a section 121 case takes months to resolve. A prisoner might not have months left. A special adjudicative body would allow for such requests to be heard with priority and decisions to be made expeditiously without compromising quality.

\section{G. KNOWLEdGe Mobilization}

Once an appropriate provision exists and is regulated, it needs to be acknowledged and made public so that prisoners and their families know that it is an option. The CSC and the PBC internet sites do not mention section 121 at all. ${ }^{142}$ Lawyers apparently do not inform their clients about it. It is likely that ordinary criminal lawyers do not know of it. Parole officers and case managers need to include compassionate release information in a package available to prisoners. ${ }^{143}$ If the criteria are regulated well enough, the risk of abuse of this provision would be minimal. Proper regulation, while more difficult, is a better way to avoid the abuse of the system than keeping prisoners uninformed.

\section{H. OVERSIGHT}

Currently, it is very difficult to obtain up-to-date information on the number of times section 121 was used and how many times it was successful. It would be useful if there was a tracking system to monitor the implementation of a new compassionate release provision. Having a special adjudicative body for these requests would facilitate the creation of such a system.

\section{Conclusion}

The continuing incarceration of very sick individuals is not serving anyone. It is not serving the correctional system that has to deal with high costs and overcrowding. It is not serving correctional officers who are increasingly being required to act as medical

$140 \quad$ See Jefferson-Bullock, supra note 72 at 563.

141 Annual Report 2012-2013, supra note 27 at 20

142 See PBC, "Mission Statement," supra note 13; Correctional Service of Canada, "Sentence Management," Commissioner's Directive No 703 (Ottawa: CSC, 10 April 2017), online: <www.cscscc.gc.ca/acts-and-regulations/703-cd-eng.shtml>.

143 The current policy is that the offender only needs to be provided with "a copy of his/her sentence calculation" and the conditional release eligibility date letter (Correctional Service of Canada, ibid). 
practitioners for older prisoners. It is not serving the taxpayers who have to pay for the incarceration of people who represent low to no risk to public safety. It is not serving prisoners who have to endure disproportionate pain and suffering. It is not serving the prisoners' families who have to sit back and watch their loved ones die behind bars while receiving inadequate medical care. Finally, it is not serving our society to see that punitiveness trumps other values, and that rights of the old and infirm are not valued. The release of a small number of prisoners on compassionate grounds may be the most humane, legally justifiable, and financially sound decision on how the correctional system should deal with the elderly and the sick. It is why an exceptional release mechanism, grounded in humanitarian reasoning, is needed. 
